\title{
Case Studies and Theories of the Arms Race
}

\author{
Matthew Evangelista*
}

Political Science Department. University of Michigan

\section{Introduction: theory and policy}

For several decades, students of the Soviet-American arms race have sought to understand its main determinants by undertaking detailed case studies of individual decisions on weapons. At times it seems that there are more arms-race 'theories' than there are weapons decisions to explain. Social scientists have called this problem 'overdetermination' - the fact that there are too many plausible explanations for the same phenomenon and no clear way of choosing between them. ${ }^{1}$

A more promising approach to case studies would focus on key factors that are claimed to influence the production of new weapons, according to a particular theory or explanation of the arms race. One could then evaluate the competing theories and identify the more powerful explanatory factors by conducting parallel case studies of similar types of decisions, both for weapons that were produced and for those that were not.

Those factors that are found both in decisions for and decisions against production should logically be considered less crucial than those that are present in decisions for, yet are missing in decisions against.

Such a method, based on a 'structured, focused comparison', cannot prove that

* Matthew Evangelista is Assistant Professor at the Political Science Department, University of Michigan, Ann Arbor; he was previously Research Fellow at Cornell University, Stanford University and at the Brookings Institution. one theory of the arms race is indisputably better than another. It does, however, offer a way to evaluate competing explanations in a more rigorous fashion and come to more meaningful (albeit, still tentative) conclusions than does the approach that relies on single case studies. ${ }^{2}$

Finally, if one is interested not only in theory, but in policy as well, one seeks an explanation that helps to indicate how to effect change. If an explanation is as complicated as reality itself, it provides no guidance. Thus, a method for identifying the strongest explanatory factors influencing the production of weapons should be of interest whether one defines one's goals as 'military reform' or 'stopping the arms race'.

The purpose of this study is to describe the problem of 'overdetermination' as it appears in explanations for NATO's weapon production and to illustrate a comparative case-study method for eliminating the weaker explanations in favor of one with greater explanatory power. ${ }^{3}$

\section{Competing explanations}

Four decisions on nuclear weapon production for NATO will be discussed here, and two explanations that seem - superficially - to account equally well for the outcomes of the decisions. The four cases are: (1) the production and deployment of Thor and Jupiter missiles in 1959-1960; (2) the decision not to produce and deploy the Multilateral Force (MLF) during the mid1960 s; (3) the decision to begin production 
of the enhanced-radiation warhead (ERW) or 'neutron bomb' in 1978; and (4) the 1979 NATO decision to produce and deploy cruise and Pershing II missiles.

The explanations both fall into the category of responses to external developments. The first - 'action-reaction' tries to explain production of new nuclear weapons for NATO as responses to Soviet initiatives. The second - the military 'fix' sees production of new nuclear weapons as an attempt to restore alliance cohesion through largely symbolic military means. These two explanations do not represent the entire spectrum of theories of the arms race. It is argued here, however, that they have figured most prominently in attempts to explain NATO nuclear decisions. It should be noted that this study does not deal with NATO nuclear relations per se. because it does not see alliance decisionmaking procedures as crucial in determining whether or not the US produces nuclear weapons for NATO. ${ }^{4}$

Action-reaction appears to work for three out of four cases: Thor-Jupiter and cruise-Pershing II were produced because they were reactions to Soviet programs (emerging ballistic missile systems and the SS-20, respectively); MLF was not produced because there was no Soviet threat that was not already countered by existing US strategic systems (and general US strategic superiority). The neutron bomb production decision is not explained by action-reaction, however. Although it was justified as an anti-tank weapon intended to offset Soviet superiority in numbers of tanks, this superiority has existed since 1945 and enhanced-radiation technology itself has existed since the late 1950s. Action-reaction does not explain why President Carter approved production of ERW components for the Lance warhead in 1978, why President Reagan approved full production and assembly of enhancedradiation weapons in 1981 or why Congress funded the W-82 ER-capable warhead in 1984.
The military fix explanation seems to work for the same cases. It apparently fits Thor-Jupiter. The decision has been described as an attempt to pull the alliance back together after the Suez crisis of 1956. The MLF could be explained as a military fix which was unnecessary and therefore unsuccessful. The explanation would go as follows: Although the Kennedy-Adenauer conflicts of the early 1960s were an alliance political problem of sufficient seriousness to warrant a 'military' solution (and the MLF was explicitly considered in this light), many observers felt that alliance doubts about the American commitment diminished in the aftermath of the Cuban missile crisis (because American resolve to risk nuclear war was demonstrated), and for this reason the MLF was no longer necessary.

Again the ERW case is an anomaly. Carter's decision to ask the Europeans to request the weapon before he would agree to produce it was not viewed as a military solution to political problems. Rather, it became a major alliance problem in itself (one of many that justified the 1979 NATO decision on political grounds, making that decision also seem to fit the military fix explanation). Reagan's decision to go ahead with production after Carter had changed his mind and deferred it certainly was not intended to mend alliance relations, and the effect was indeed the opposite.

\section{Technological entrepreneurship}

We shall now focus on the anomalous case of the neutron bomb and try to construct an alternative explanation to account for those developments that action-reaction and the military fix fail to explain. The explanation emphasizes internal determinants for most of the decision process, in particular the bureaucratic forces that promote new weapons technologies. It tries to incorporate external factors at the later stages of the process, suggesting that they provide a 'window' through which the 
new weapon can be promoted. By incorporating both internal and external factors the explanation seeks to avoid the unproductive debate that followed the original presentation of the Eigendynamik (selfgenerating, internal dynamic) model. 5 Clearly the arms race is driven by both internal and external determinants. The important task is to identify which factors come into play at which stage, and to be willing to set aside those factors that do not have great bearing on the decision.

\subsection{The neutron bomb: internal pressures}

The neutron bomb is a particularly useful case for evaluating competing explanations. One needs to address the question, 'why was a weapon that was invented in 1958 not produced until the late 1970 s?' If the conditions for an action-reaction or military-fix explanation existed during this period, they were not sufficient to lead to the weapon's production. An alternative explanation is needed - one that can account for the weapon's lack of success for twenty years as well as its ultimate production.

The concept of a warhead that kills primarily with neutron radiation was considered during the development of the hydrogen bomb in the late 1940s. ${ }^{6}$ During the debate over whether to build the hydrogen bomb, its opponents - most notably, J. Robert Oppenheimer - argued in favor of development of tactical nuclear weapons as an alternative to strategic bombing. Proponents of the H-bomb, including Edward Teller, in turn argued that fusion weapons themselves could have high tactical value on a battlefield.' Thus, while much of the research conducted at Teller's Livermore Laboratory from its founding in 1952 involved high-yield fusion weapons, by the late 1950s considerable work was being done on lower-yield weapons for tactical use. The main breakthrough came in 1958, as a result of the work of Samuel Cohen, then a physicist at the RAND Corporation. ${ }^{8}$
Through his contacts in the Air Force, Teller was able to get its Science Advisory Board to establish a panel to investigate the technical feasibility of the enhancedradiation concept. The panel, chaired by Cohen, presented its findings to the Air Force in the fall of 1958 , to an unenthusiastic response. ${ }^{9}$

Teller, Cohen, and the other ERW supporters next tried to sell their idea to the Navy. Despite some initial interest, however, the Navy did not pursue enhancedradiation warheads for its weapons. The likely reason is that by the late 1950s most of the navy's nuclear programs centered around nuclear-powered missile-carrying submarines which had no use for ERWs and did not need the budgetary competition. ${ }^{10}$

When Teller's efforts to interest the Air Force and Navy in producing ERWs proved futile, he turned to the executive and legislative branches of the US government and to the civilian leadership of the Defense Department. Captain John Morse, in his capacity as assistant to the chairman of the AEC, tried to reach the President directly through drafting a memorandum in support of 'clean' weapons for tactical use. ${ }^{11}$ Samuel Cohen was also in direct contact with the White House, through the President's aide, Major John Eisenhower. In November 1959, the President himself was briefed on the ERW. ${ }^{12}$

The extensive briefings conducted by Samuel Cohen and other weapons lab scientists attracted some public attention, and information concerning enhanced-radiation weapons and the scientists' lobbying efforts appeared in the Washington Post and other publications, as early as 1959 . Teller and his colleagues were by this time mainly trying to convince the Army to adopt ERWs as tactical weapons. The fact that Teller and Cohen turned to the Army only after unsuccessful attempts to interest the Air Force and Navy in ERWs belies the popular impression that Cohen created the 
ERW primarily as a battlefield anti-tank weapon for European use. As Cohen himself writes, "keep in mind that it was in the context of Asian scenarios that the neutron bomb was first conceived'. ${ }^{13}$

In any case, Teller and Cohen were not able to secure Army support for production of the ERW as a tactical weapon. Army officials were particularly skeptical about the ERW's effectiveness as an antitank weapon, based on experimental data indicating 'that only within a relatively small area near the explosion would the enemy troops be instantly incapacitated. Troops occupying a much larger area would be injured, though before death they would remain capable of fighting for at least some time after the irradiation. '14

Thus, the scientific promoters of the neutron bomb were unable to interest any of the military services in adopting it as a battlefield nuclear weapon. The Air Force preferred its strategic missile and bomber programs: the Navy favored its Polaris system; and the Army was preoccupied with the Vietnam War and later with stewardship of the Sentinel ABM program. The scientists were able to gather enough support for 'clean' enhanced-radiation weapons to defeat the comprehensive test ban, but not enough to produce the weapons themselves. They had the backing of the Atomic Energy Commission, the Joint Committee on Atomic Energy, and the Defense Department, but without the sponsorship of a particular service they could not proceed. 15

\subsection{The neutron bomb: a window opens}

During the early 1970s, the nuclear weapons laboratories, which had continued work on enhanced-radiation weapons, launched a vigorous campaign to promote their use on the battlefield. In congressional testimony in 1973, Harold Agnew, director of the Los Alamos lab, clearly referred to ERWs when he said:

I know we at Los Alamos have a small, but very elite group that meets with outside people in the defense community and in the various think tanks. They are working very aggressively, trying to influence the DOL (Department of Defense) to consider using these (deleted) weapons which could be very decisive on a battlefield, yet would limit col. lateral damage that is usually associated with nuclear weapons. ${ }^{16}$

Here Agnew spells out the basis for the 'technological entrepreneurship' explana. tion used in this comparative study. Es. sentially, it refers to a technological program of long standing and developmen1 being actively promoted by weapons designers until it finds support among thinktank analysts, elected officials, and US and NATO military leaders. At a later stage, this process is often facilitated by the appearance of a 'window of opportunity' in the form of a Soviet military program or alliance crisis, by which the weapon can be justified.

In this case of the neutron bomb, it was not an 'external factor' of this sort, but an internal development that provided the window. The main problem for the weapon's promoters was the lack of a military sponsor. The Army continued to reject ERWs in favor of standard nuclear warheads, on grounds of military effectiveness. In 1973, for example, the Army submitted a request to modernize its nuclear artillery, but was turned down by the joint Committee on Atomic Energy, led by Senator Stewart Symington.

The Army somewhat reluctantly came to support development of neutron warheads as the only possibility of getting any nuclear artillery at all. Having had its modernization proposal rejected by Congress, it could not simply come back with the same proposal. Therefore, on 29 August 1973, immediately following the congressional rejection, the Army Chief of Staff drew up a memorandum directing a study to 'reexamine' nuclear-warhead requirements for artillery projectiles. According to Samuel Cohen, the memorandum 'requesting the study is full of radiation-dose 
requirements for incapacitating military personnel', with the concomitant requirement to 'minimize collateral damage', i.e., 'damage to civilian structure'. 'In other words', Cohen writes, 'the memo directed a neutron bomb study'. ${ }^{17}$

Despite the new-found support of the Army, a key obstacle to production of ERWs remained - in the person of Senator Symington. When Symington retired from the Senate in 1976, there was nothing further to hinder the approval of ERW production. Symington's Joint Committee on Atomic Energy was dissolved and its duties assumed by the Senate Armed Services Committee; its chair was Senator John Stennis and its membership included Senators Henry Jackson and Strom Thurmond - all strong proponents of tactical nuclear weapons. With Symington out of the way, the Energy Research and Development Administration (successor to the Atomic Energy Commission) was able to include a production request for ERWs for the Lance missile in the President's annual stockpile review of 24 November 1976. President Ford approved the request, as did the Senate Armed Services Committee in hearings the following March. ${ }^{18}$

The ERW production request was first discovered and publicized by Washington Post reporter Walter Pincus, who found mention of it in Senate Appropriations Committee hearings on ERDA's Fiscal Year 1978 public works bill. Pincus published a story in the Post on 6 June 1977 entitled 'Neutron Killer Warhead Buried in ERDA Budget'. This was the first that most people had heard of the ERW.

The rest of the neutron-bomb story has been covered well elsewhere. ${ }^{19}$ President Carter's indecision about whether to produce the weapon - while quite divisive for the NATO alliance - did not ultimately affect ERW production. Carter decided in April 1978 to defer production, but six months later ordered the Department of Energy to produce ER components. In October 1978, production activities began on the W70-3 enhanced-radiation warhead for the Lance missile. Several hundred have now been built and are stored in the United States, ready to be deployed to Europe in the event of war or if NATO allies request them. ${ }^{20}$

The latest chapter in the neutron-bomb saga further confirms the validity of the 'technological-entrepreneurship' explanation. During the spring of 1984, General Bernard Rogers, Supreme Allied Commander, Europe, engaged in a major lobbying effort to get congressional approval for the W-82 warhead for NATO's $155-\mathrm{mm}$ artillery - a warhead that can be made into an enhanced-radiation weapon through the simple insertion of a tritium module. At an estimated cost of 2.6 million dollars each, the new warhead was not popular with the Congress. Its proponents were able to convince a couple of key senators to support the weapon. These senators then attached an amendment to the Defense Authorization Bill to fund the W-82. By deceptively characterizing the amendment as one that would prohibit production of enhanced-radiation shells (in fact it only prohibits their final assembly), and by introducing the amendment during an all-night session, the sponsors were able to get it passed without a roll-call vote at 3:00 A.M. on 21 June 1984. ${ }^{21}$

Thus, the technological-entrepreneurship explanation emerges as the most convincing in accounting for the ERW production decisions.

\subsection{Internal pressures and NATO's nuc- lear weapons}

The main elements of the technological entrepreneurship explanation are the following: (1) a longstanding technological program strongly backed by the private or governmental weapons laboratories responsible for its development; (2) support within the military, the academic community of 'defense intellectuals', the State Department, and the relevant committees of the Congress; and (3) justification for 
the weapon on the basis of long-term NATO plans. The factors which appear less important are (1) support from alliance political (or even military) leaders in Europe: (2) public support: or (3) a genuinely new Soviet threat (as opposed to an old threat used as a pretext). At a later stage these factors may come into play and improve the prospects for the new weapon.

The other cases considered in this paper reveal a similar pattern. Analysis of these cases calls into question the action-reaction and military-fix explanations. In the case of the Thor and Jupiter missiles, for example, both had received wide support within the government long before the first detection of Soviet missile tests in 1955.

By the same token, the military-fix rationale seems weak. Even before the British-French-Israeli invasion of $\mathrm{Suez}$ in 1956, the US had secured an agreement in principle to deploy Thor missiles in Britain. The countries that received the Jupiter missiles - Italy and Turkey - were not involved in the Suez crisis; their relations with the US had not suffered; so there was nothing to 'fix'. One major study of the issue argues that the effect of the decision was in fact to worsen relations. That study finds the sources of the Thor-Jupiter decision mainly in the promotion of a novel technology (ballistic missiles) by military bureaucracies - in other words, what is termed here 'technological entrepreneurship'.22

Arguments against the action-reaction and military-fix explanations are more familiar for the case of the Pershing II and cruise missiles. They were not developed as responses to the Soviet SS-20 and Backfire bombers or as solutions to alliance political problems. These later events provided a 'window' through which supporters could push weapons that they favored for other reasons. The Pershing II, for example, originated with a 1969 contract to the Martin-Marietta Corporation, intended to fulfill a broad requirement for accurate, low-yield, nuclear weapons, dictated - according to some views - by NATO's doctrine of 'flexible response'. Cruise missiles had also been promoted for many years, especially by military analysts who favored their use as conventional weapons. ${ }^{23}$

The military-fix rationale has its difficulties as well. First, one has to consider whether the concern about the US commitment to Europe originated with European elites, or was induced by certain American opponents of arms control. As one analyst has argued, (i)n view of the transatlantic interchange of ideas among the small group of government officials and observers who are involved in nuclear issues, and taking account particularly of the sniping at the SALT process by various Americans, it is difficult to apportion responsibility' for the missile decision to the Europeans. 'If some European became concerned over America's intentions it is necessary to ask who encouraged and at times fuelled these suspicions. " 24 The reference here is undoubtedly to Helmut Schmidt, who many still erroneously believe called for the missile deployment in 1977. In evaluating the military-fix explanation, one also has to ask why a military solution was deemed necessary, when in the past alliance cohesion has been restored through political means. ${ }^{25}$ One is drawn to the conclusion that problems of alliance cohesion are not sufficient to explain the emergence of Pershing II and cruise missiles.

The case of the Multilateral Force is particularly interesting because it shares many elements with the cases in which new nuclear weapons were produced. Yet in this case a decision was made to abandon the MLF. Do the action-reaction and military-fix explanations account well for the decision? The analysis presented in this paper suggests that they do not. An actionreaction interpretation would argue that there was no military need for a Europeanbased nuclear force, owing to overall US strategic superiority. Many prominent ob- 
servers argued, however, that the US did not have meaningful or useful superiority after the Soviets had managed to build a force of long-range bombers and missiles that could attack the United States during the early 1960s. This was Secretary of Defense Robert McNamara's view during the Cuban missile crisis, for example. At the same time, a number of officials - including General Lauris Norstad, Supreme Allied Commander, Europe - advocated achieving a 'theater balance' in Europe in order to make NATO a 'fourth nuclear power'. He spoke of Soviet superiority in land-based medium- and intermediaterange ballistic missiles - a force that grew from 500 systems in 1962 up to nearly 750 by 1967 . By the action-reaction explanation, some NATO counterweight should have been produced.

The military-fix explanation for the failure of the MLF would have to argue that problems of alliance cohesion were not sufficiently great to prompt a 'military' solution. Some analysts point to the formation of the Nuclear Planning Group in 1967 as a substitute for military hardware. This begs the question, why was a political rather than a military solution adopted?

The technological-entrepreneurship explanation would argue that the main reason the MLF failed was because it was not based on a technological program with longstanding support among weapons scientists, industrial R\&D labs, or any military service. Instead, the MLF incorporated a technological system - the Polaris missile - that was already being developed at full speed by Admiral Hyman Rickover for his submarine fleet. Thus, a key ingredient for successful technological entrepreneurship was missing. Most of the other ingredients were, however, present. The MLF had strong backing within the State Department, among a number of NATO governments, and from General Norstad and his colleagues at NATO headquarters.
4. The 'requirements' of alternative explanations

Readers may not agree with the explanation that emerges from this analysis as the strongest - what is called here 'technological entrepreneurship'. Any competing explanation should, however, be able to account for the same phenomena at least as well.

One explanation that claims to do so focuses on the 'requirements' of US or NATO doctrine. This explanation has been put forward most recently to justify the production of Pershing II and cruise missiles. ${ }^{26}$ It argues that official doctrine, be it 'massive retaliation' or 'flexible response', determines which weapons are produced.

There are a number of problems with this explanation. The nature of US and NATO doctrine is too amorphous and even self-contradictory to set any definite requirements for weapons. Manfred Wörner, West German Defense Minister, made this point clearly in regard to 'flexible response', arguing that the doctrine 'is formulated as vaguely as it is because the interests of all NATO countries must be straddled."

The United States is obviously interested, in the event of a breakdown of the deterrent in Europe, in containing the military conflict to the Continent as long as possible - in keeping it from escalating and prevailing on the battlefield without endangering American terriroty. By contrast, it is in the European interest that the risk for the aggressor be heightened by the prospect of a relatively quick escalation of the battle.

Wörner points out that this 'conflict of interest is probably irreconcilable'. ${ }^{27}$

It seems reasonable to add that determining weapons requirements on the basis of an irreconcilable conflict of interests would be mainly a matter of opinion (or self-interest). Does filling a 'gap in the escalation spectrum' make escalation more certain, or does it increase the prospects for 'decoupling'? When, according to NATO doctrine, does strategic parity 
between the superpowers demand new theater and tactical weapons and when does it not? Certain NATO strategists have argued since the mid-1950s that the existence of parity - or 'nuclear stalemate', as it was often called then - demanded new weapons for NATO. ${ }^{28}$ These views still serve as the rationale for new intermediaterange missiles, modernized nuclear artillery, and enhanced-radiation warheads for tactical rockets. In what sense does doctrine explain the production of all these weapons? It is argued here that 'technological entrepreneurship' is a better explanation.

\section{Conclusion and implications}

The type of explanation one perceives as strongest in accounting for weapons production suggests the kinds of prescriptions one would make in order to change current policy. Action-reaction interpretations that see NATO nuclear weapons as necessary rational responses to Soviet initiatives, logically view Soviet restraint as the only means of slowing the arms race. Believers in military-fix explanations are held hostage to the vagaries of alliance relations, while those who accept doctrine as the main determinant of new weapons must also accept official definitions of the 'requirements' of doctrine.

An explanation based on the notion of 'technological entrepreneurship' does suggest ways to influence policy. Some apparent means of countering the bureaucratic promoters of new technological concepts and weapons include a better informed public and more responsive legislators. In a sense, the latter follows from the former.

Another important component of a strategy to counter the bureaucratic and technological forces that propel the arms race is a community of independent experts who can provide alternative analysis of security issues. This is not to suggest that such a community should be considered merely the servant of popular movements. Rather, as this paper has attempted to demonstrate, methodologicallygrounded historical studies can contribute both to academic debates as well as provide some insights for those interested in influencing policy.

\section{NOTES}

1. For a discussion, in the context of the arms race, see James Kurth, 'A Widening Gyre: The Logic of American Weapons Procurement', Public Policy 19 (Summer 1971), pp. 373-404.

2. This method has been described and illustrated in a number of works by Alexander George, most recently in a chapter with Timothy J. McKeown, 'Case Studies and Theories of Organizational Decision Making . Advances in Information Processing in Organizations, Vol. 2, pp. 21-58. For earlier discussions, see A. L. George, 'Case Studies and Theory Development: The Method of Structured, Focused Comparison'. in P. G. Lauren, ed., Diplomacy: New Approaches in History, Theory, and Policy (New York: Fee Press, 1979), pp. 43-68: and A. L. George and R. Smoke, Deterrence in American Foreign Policy: Theory and Practice (New York: Columbia University Press, 1974).

3. The paper summarizes a longer study of decisions on production of nuclear weapons for NATO. See M. Evangelista, Explaining NATO's Nuclear Weapons, Occasional Paper of the Peace Studies Program. Cornell University, and the Hessische Stiftung Friedens- und Konfliktforschung, 1986.

4. For general discussions of NATO nuclear relations, see David N. Schwartz, NATO's Nuclear Dilemmas (Washington, DC: Brookings Institution, 1983); and Paul Buteux, The Politics of Nuclear Consultation in NATO 1965-1980 (Cambridge, UK: Cambridge University Press, 1983). For an excellent study of the domestic politics of nuclear decisions in the Federal Republic of Germany, see Thomas Risse-Kappen, 'Fahrplan zur Abrustung'? Zur INF-Politik der Bundesrepublik Deutschland 1970-1983 (Frankfurt/Main: HSFK-Forschungsbericht, 1985). For a consideration fo Soviet decisions, see M. Evangelista, 'Why the Soviets Buy the Weapons They Do'. World Politics, Vol. 36, No. 4 (July 1984), pp. 597618.

5. The explanation presented here shares some features with the one discussed in a somewhat broader context by Eugene 
Lewis, Public Entrepreneurship: Toward a Theory of Bureaucratic Political Power (Bloomington: Indiana University Press, 1980). For a comprehensive presentation of the Eigendynamik model, see Dieter Senghaas, Rüstung und Militarismus (Frankfurt/Main: Suhrkamp Verlag. 1972) pp. 246-259.

5. George B. Kistiakowsky, The Folly of the Neutron Bomb', Bulletin of the Atomic Scientists (September 1978), pp. 25-29.

7. These views are put forward, for example, in letters to President Harry Truman from Brien McMahon, Chair of the Joint Committee on Atomic Energy of the Congress, 21 November 1949, and from Lewis Strauss, member of the Atomic Energy Commission, 25 November 1949, in the Papers of Harry S. Truman, Naval Aide File, Box 13, Folder: Atomic Energy, Harry S. Truman Library, Independence, Missouri. The case is discussed in $\mathbf{M}$. Evangelista, Technological Innovation and the Arms Race: A Comparative Study of Solict and American Decisions on Tactical Nuclear Weapons, Ph. D. dissertation, Cornell University, 1986, Chapter 3.

8. Samuel T. Cohen, The Neutron Bomb: Political, Technological and Military Issues (Cambridge, MA: Institute for Foreign Policy Analysis, 1978) p. 5; and Cohen, The Truth About the Neutron Bomb (New York: William Morrow, 1983), pp. 34-35.

9. Cohen, The Neutron Bomb, pp. 4-9: The Truth About the Neutron Bomb. pp. 36, 41 .

(). As Cohen himself put it, Navy opponents of the ERW were 'spreading the world around" the Pentagon that the Polaris submarines 'were going to be doomed by neutron weapons'. The Truth About the Neutron $B o m b$, p. 51. For the role of Morse, ibid., pp. $14,42-44,47-55$.

1. Morse's efforts are extensively documented in the archives of the Dwight D. Eisenhower Library in Abilene, Kansas. See the Records of the Office of the Special Assistant for National Security Affairs, OSB Series, Subject Subseries, Box 1, Folders: Atomic Energy Commission - General (7) and (9): Box 4, Folder: Nuclear Energy Matters (3) and (4).

2. The report by Cohen was declassified with some deletions, at the request of this author. See Samuel T. Cohen, Low'Yield Fusion Weapons for Limited Wars (deleted). RAND Corporation Report R-347, I June 1959, located in the Office of the Staff Secretary: Records 1957-61, Subject Series, DoD Subseries, Box 3, Folder: Defense Classified (1), Eisenhower Library. John
Eisenhower indicated in writing on the report that the President was briefed on 10 November 1959. See also the letter from Cohen to John Eisenhower, 23 September 1959, ibid.

13. See Edward Gemarekian, 'New A-Bomb "Pinpoints" Lethal Dose: Could Make Test Ban Meaningless', Washington Post, 19 July 1959. See also Cohen, The Neutron Bomb, p. 12., and The Truth About the Neutron Bomb., p. 15.

14. Kistiakowsky, 'The Folly of the Neutron Bomb', p. 25.

15. See the discussion in Sherri L. Wasserman, The Neutron Bomb Controversy: A Study in Alliance Politics (New York: Praeger. 1983), pp. 24-27.

16. Military Applications of Nuclear Technology, Hearings before the Subcommittee on Military Applications, Joint Committee on Atomic Energy, 16 April 1973, Part I, p. 49.

17. Cohen, The Truth About the Neutron Bomb, p. 100.

18. Energy Research and Development Administration Fiscal Year 1978 Authorization, US Senate, Committee on Armed Services, 25 March 1977 (Washington, DC: US Government Printing Office, 1977), pp. 4, 7. 30-31.

19. For example, Milton Leitenberg, 'The Neutron Bomb - Enhanced Radiation Warheads', Journal of Strategic Studies, Vol. 5, No. 3 (September 1982), pp. 34I369.

20. Thomas B. Cochran, William M. Arkin, Milton M. Hoenig, Nuclear Weapons Databook, Volume I: US. Nuclear Forces and Capabilities (Cambridge. MA: Ballinger, 1984), p. 72. William M. Arkin and Richard W. Fieldhouse, Nuclear Battlefields: Global Links in the Arms Race (Cambridge, MA: Ballinger, 1985), p. 60.

21. This account follows Christopher Paine, 'Senator Nunn's Shell Game', Bulletin of the Atomic Scientists (February 1985), pp. 5-8.

22. See Michael H. Armacost, The Politics of Weapons Innovation: The Thor-Jupiter Controversy (New York: Columbia University Press, 1969), p. 181.

23. On the domestic sources of the two decisions, see Christopher Paine, 'Pershing II: The Army's Strategic Weapon', Bulletin of the Atomic Scientists (October 1980), pp. 25-31; and Robert J. Art and Stephen E. Ockenden. 'The Domestic Politics of Cruise Missile Development, 1970-1980', in Richard K. Betts, ed., Cruise Missiles: Technology, Strategy, Politics (Washington, DC: 
Brookings Institution, 1981), pp. 359-413.

24. Simon Lunn. 'Cruise Missile and the Prospects for Arms Control,' ADIU Report (September/October 1981), pp. 4-5. See also the account by Fred Kaplan, 'Warring over New Missiles for NATO', New' York Times Magazine, 9 December 1979, pp. 46ff; and the discussion by Raymond L. Garthoff, Detente and Confrontation: American-Soviet Relations from Nixon to Reagan (Washington, DC: Brookings Institution, 1985). Ch. 25, esp. pp. 854-870.

25. Jane M. O. Sharp, 'Arms Control and Alliance Commitments', Political Science Quarterly, Vol. 100, No. 4 (Winter 1985-86), pp. 649-667.

26. See, for example, James A. Thomson, The LRTNF Decision: Evolution of US Theatre Nuclear Policy, 1975-9', International Affairs, Vol. 60. No. 4 (Autumn 1984), pp. 601-614: and J. M. Legge. Theater Nuclear Weapons and the NATO Strategy of Flexi- ble Response (Santa Monica, CA: RAND Corp., 1983).

27. Manfred Wörner, 'NATO Defenses and Tactical Nuclear Weapons', Strategic Review (Fall 1977), reprinted in Wolfram F. Hanrieder, ed., Arms Control and Security: Current Issues (Boulder, CO: Westview. 1979). p. 259. For a good discussion of the contradictions inherent in 'flexible response' and a skeptical evaluation of the rationales for the Pershing II and cruise missile deployments, see Leon V. Sigal, Nuclear Forces in Europe: Enduring Dilemmas and Present Prospects (Washington. DC: Brookings Institution, 1984), ch. 3.

28. See, for example, Henry A. Kissinger, Nuclear Weapons and Foreign Policy (New York: Harper, 1957): and the extensive bibliography in Morton H. Halperin, Limited War in the Nuclear Age (New York: John Wiley and Sons. 1963). 